\title{
COMPARATIVE ANALYSIS OF DETERMINING THE MARKET VALUE OF FOREST REAL PROPERTIES USING VARIOUS VALUATION TECHNIQUES
}

\author{
Małgorzata Buśko, PhD \\ Faculty of Mining Surveying and Environmental Engineering \\ AGH University of Science and Technology \\ e-mail:mbusko@agh.edu.pl
}

Abstract
The paper presents procedures for determining market values of forest real properties, with particular emphasis placed on the forest stand. The mixed-approach valuation procedure - land valuation index method - was analyzed. The practical part of the work regarding the valuation of the forest stand introduces the various techniques of valuation and acquisition of data on forest resources used, i.e.: index-based valuation approach and stock survey approach.

The subject of the research is part of a forest property, which represents an assessment area, typical of the southern part of Poland, located in the Tenczynek Forest Division. There is a forest management plan for the analyzed property which, together with the assessment descriptions, was used as one of the sources of data for valuation. The second source of data for valuation were direct field surveys, i.e.: geodetic surveys for determining the assessment area and the stock survey approach with individual tree assessment with respect to data on the stand.

Based on the research, it may be concluded that both valuation techniques and methods used to capture data on forest resources significantly affect the final value of forest properties. The market value of the stand, determined by the index-based valuation approach, demonstrates a significant difference when compared to the value of the stand determined by the stock survey approach. The forest management plan should only be used as a supplementary material and only to identify site types of forests by property valuers and, partially, together with economic maps, to determine the boundaries of assessment areas.

Key words: valuation of the stand, market value, forest property, public forests, stock survey.

JEL Classification: $R 33$.

Citation: Buśko M., 2018, Comparative Analysis of Determining the Market Value of Forest Real Properties Using Various Valuation Techniques, Real Estate Management and Valuation, vol. 26, no. 1, pp. 51-62.

DOI: $10.2478 /$ remav-2018-0005

\section{Introduction}

This paper presents issues related to determining the market value of forest real properties taking into account their components - land and stand. Valuation was conducted using a mixed approach - the land valuation index method. Two techniques were used for the valuation of the stand: the indexbased valuation approach and stock survey approach. Both, the valuation technique and the method of data acquisition regarding forest resources significantly affect the final value of a forest property.

The thesis which was formulated stipulates that the market value of a forest property, and especially of its stand, determined by the index-based valuation approach based on the forest management plan and using Partyka - Trampler tables (PARTYKA, TRAMPLER 1991), demonstrates a significant difference compared to the value of the stand determined by the stock survey. 
To validate this thesis, a representative subarea located in the Tenczynek Forest Division was selected, the stand of which was valued using two valuation techniques, including the most accurate one of individual tree assessment.

The subarea, where the leading species occurs, may be considered to be representative of southern Poland; however, there is also a local occurrence of other species. These locally occurring other species are omitted numerically in assessment descriptions in the forest management plan, resulting in large discrepancies between the values of the stands obtained using the two methods.

A comparative analysis of the process and the results of forest property valuation was carried out accounting for various valuation techniques, and factors which significantly affect the market value of forest real properties, especially their component - the stand, were identified. The present study refers only to the current legislation on real estate valuation. However, due to the lack of legal regulations regarding certain issues related to forest property valuation, the study also includes recommendations contained in the Interpretative Note, i.e., Professional Standard V.6 (STANDARD 2004), which has the status of recommended for use.

\section{Literature review}

Today, forests cover about $30 \%$ of Poland's territory. Forests in Poland can be divided into two groups. The first one includes public forests and the other - private forests. Public forests, owned by the State Treasury, cover about $81 \%$ of the whole forest area in Poland (CSO 2016). On behalf of the State Treasury, public forests are managed by the National Forest Holding State Forests; some also form national parks, others are owned by municipalities, and others still are included in the Agricultural Property Stock of the State Treasury. The group of private forests (about 19\%) includes land owned by natural persons, private enterprises, production cooperatives, agricultural cooperatives, land communities, or churches and religious associations (Fig. 1).

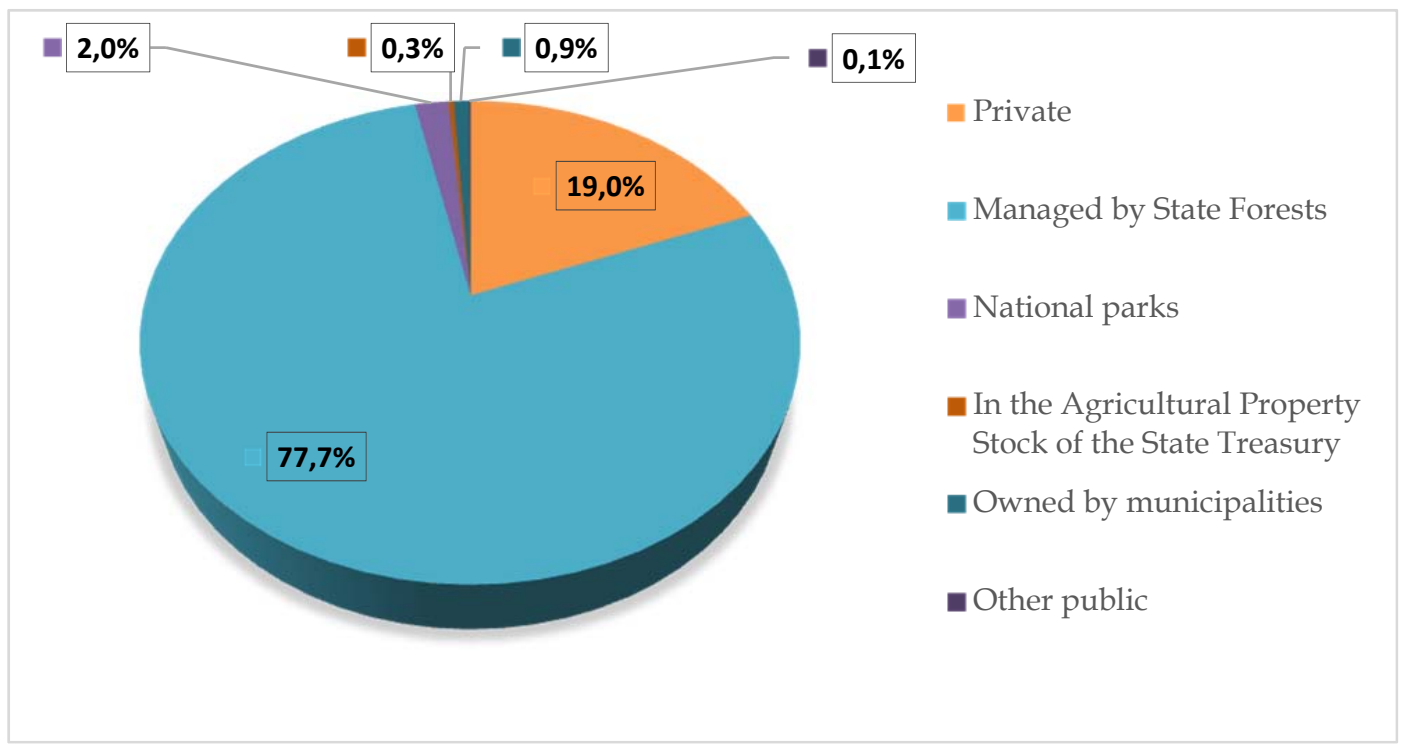

Fig. 1. Ownership structure of forests in Poland. Source: own study based on (CSO 2016).

Harmonious and rational management of public forests is carried out through the division of forest areas into administrative units - forest inspectorates. A forest inspectorate is divided into a forest district, and a forest district - into forest sub-districts. Sub-districts are divided into the smallest units - forest ranges (also referred to as subareas or assessment areas). These are valuation units that form the basis for the preparation of the forest management plan.

According to the Forest Act (ACT 1991), a forest management plan is drawn up every 10 years for forests managed by the State Forests. Detailed guidelines for its preparation are provided in the Forest Management Guideline of 2012 (GUIDELINE 2012). The issue of preparing of a forest management plan and its application in forest stand valuation was widely discussed in (BALAWEJDER et al. 2015). Preparation of management and forestry documentation is preceded by inventories of individual subareas, where the surfaces of subareas are corrected with reference to the plan from the previous decade. In addition, an inventory of the volume of forest resources, soils and sites is carried out. The 
value of forest property is influenced by various factors (WILKOWSKI 2013); however, the manner and method of performing inventories of forest resources play a key role and significantly affect the final outcome of forest property valuation. Innovative solutions for performing inventories of forest resources, such as those based on the point cloud method presented in (MIKITA et al. 2016), can be found in scientific literature. The possibility of using remote sensing in forest inventories has also been analyzed in (CROSBY et al. 2017). A survey of resources regarding soils is presented in (VAYSSE, LAGACHERIE 2017) or in (SCHWEIZER et al. 2017). It has been emphasized that increased efficiency of determining biomass is performed at the expense of accuracy. An inventory of resources with reference to tree species is presented in (MOHAMMADI et al. 2017). A very interesting study on the spatial modeling of plant distribution in the aspect of the conducted inventories is presented in (ABDOLLAHNEJAD et al. 2017). Knowledge of the basic principles and assumptions that underpin the right approach to valuation and its procedures is extremely important. The thesis that knowledge of economic principles of valuation improves its quality and allows for more accurate interpretation of valuation results was proved in the paper (KUCHARSKA-STASIAK, ŹRÓBEK 2015). Comparative values, as results of actions regarding the same issues, frequently differ, depending on the source of their acquisition (DUDZIŃSKA, KOCUR-BERA 2014). Issues of forest property valuation are also subject to other interesting studies, e.g. (ZAJĄC 2013). Research on the possibilities and effects of using various techniques to determine the value of forest stands was also carried out in the study (WILKOWSKI 2011).

In practice, the valuation of forest properties, including forest land and its components - forest stands, is not explicitly defined in the applicable legislation. Art. 152 of the Real Estate Management Act (ACT 1997) presents methods of determining the market value of real estate by recommending a proper approach to valuation. With regard to forest stand valuation in connection with the expropriation procedure, Art. 135 Section 5 of the Act contains only general guidelines related to determining the replacement value of the stand. It is stated that, when determining the value of a forest stand, if there are usable materials in this stand, then the value of wood is estimated, and if there are no usable materials in the stand - the cost of afforestation and care. Other than that, the Act does not contain any provisions on forest stand valuation. The principles of forest land valuation are somewhat clarified in secondary legislation to the Act, i.e. in the Regulation on real property valuation and preparation of a property valuation survey, issued subject to Art. 159 of the Act (REGULATION 2004). However, due to the lack of clarity in all regulations concerning forest property valuation, the Professional Standard V.6 for professional property valuers was developed (STANDARD 2004). Therefore, property valuers evaluate forest stands based only on an instructional standard - such as the above-mentioned one, which has the status of recommended for use.

\section{Data and Methods}

The value of forest property is the sum of the value of forest land and its components, such as stands, plantations and single trees, which can be written as:

$$
\mathrm{W}_{\mathrm{N}}=\mathrm{W}_{\mathrm{G}}+\mathrm{W}_{\mathrm{D}}
$$

where:

$\mathrm{W}_{\mathrm{G}}$ - market value of the land,

$\mathrm{W}_{\mathrm{D}}$ - value of forest stand.

Pursuant to $\$ 18$ Section 1 of the Regulation on real property valuation and preparation of a property valuation survey (REGULATION 2004), in the absence of market transactions, in order to determine the value of real estate intended for agricultural and forestry purposes, the land valuation index method shall be used. Using this method, the value of forest land for a single subarea may be written as follows:

$$
W_{G}=\sum_{i=1}^{n} N_{i} \times P_{i} \times c \times\left(1+v_{1}+v_{2}+v_{3}+\cdots\right)
$$

where:

$$
\begin{aligned}
& \mathrm{W}_{\mathrm{G}} \quad \text { - market value of forest land, } \\
& \mathrm{Ni} \quad \text { - valuation index for } 1 \text { ha of land, depending on the tax district, valuation class, and contour } \\
& \text { of forest site type, } \\
& \mathrm{P}_{\mathrm{i}} \quad \text { - surface area of the i-th contour expressed in ha, according to assessment description data, } \\
& \text { or according to field surveys, }
\end{aligned}
$$


- price of $1 \mathrm{~m}^{3}$ of timber as a weighted average over the past 3 years, taking into account the grade of the timber sold, costs of harvesting timber and skidding, taken from the local market or locally competent forest inspectorate, respectively,

$\mathrm{v}_{\mathrm{i}} \quad$ - forest land value correction factors, taking into account specific market characteristics.

Correction factors $\left(\mathrm{v}_{\mathrm{i}}\right)$ are determined by a property valuer. They take into account particular characteristics of forest properties. It is recommended that the market characteristics of properties, the extent of their assessment and the resulting values of correction factors be taken from the commentary to the Professional Standard V.6 (COMMENTARY 2004).

As far as the stand is concerned, if it is older than 20 years, its market value is determined according to the value of timber in the trunk. Two valuation techniques can be distinguished:

- stock survey approach,

- index-based valuation approach - based on updated data contained in the forest management plan.

Valuation of the analyzed stand was carried out using both techniques, as illustrated in the diagram below (Fig. 2).

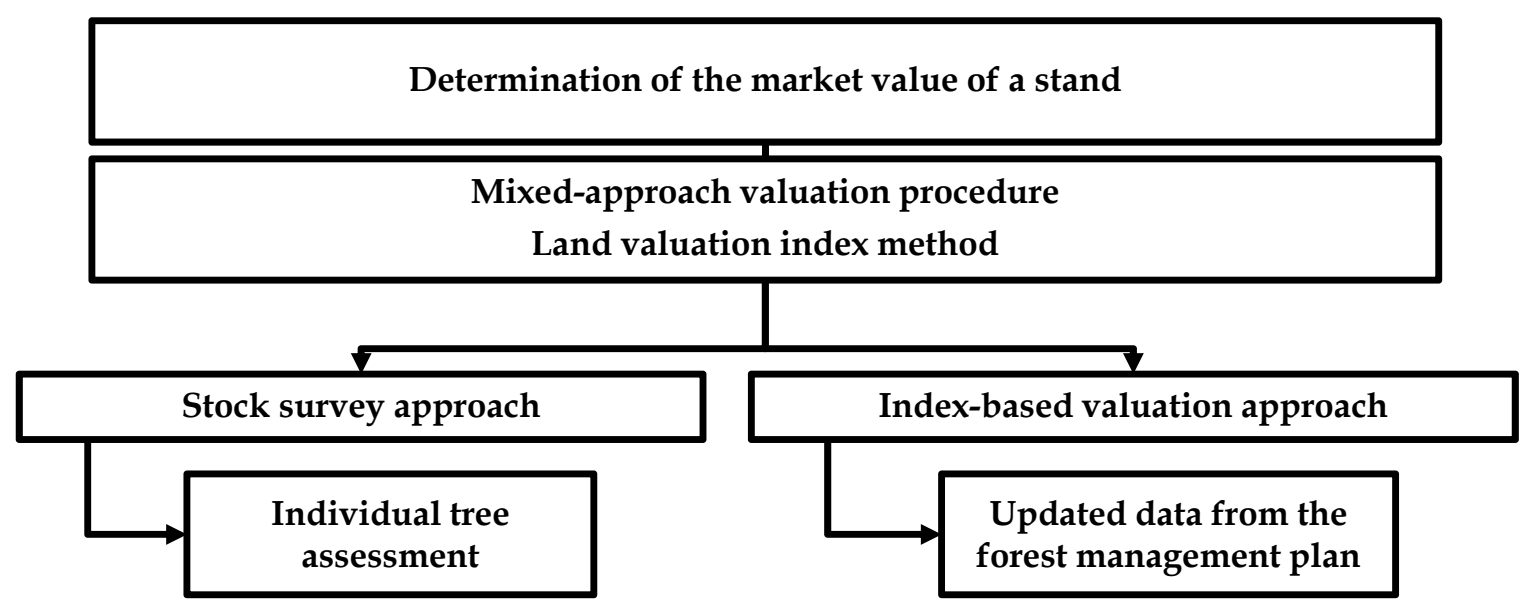

Fig. 2. Procedure for determining market value of the stand. Source: own study.

According to Professional Standard V.6, when implementing the stock survey approach, it is necessary to determine the total volume index and the share of particular types of timber grades using one of the methods presented in the diagram in Fig. 2. The study used the individual tree assessment method, as the method best describing the stands existing in the field. Then, the following formula was used to calculate the final value of the stand:

where:

$$
W_{D}=\left[\left(V_{G} \times r_{i}\right) \times\left(k_{1} \times U_{1} \times C_{1}+k_{2} \times U_{2} \times C_{2}+\cdots+k_{n} \times U_{n} \times C_{n}\right)+V_{D R} \times k_{D R} \times C_{D R}\right]
$$

$\mathrm{V}_{\mathrm{G}} \quad$ - gross volume (including bark) of a specific species of trees occurring in the stand,

$r_{i} \quad$ - coefficients for the calculation of net volume (excluding bark),

$\mathrm{k}_{\mathrm{i}} \quad$ - index of the share of specific timber grades in the total volume, determined based on the stock survey,

$\mathrm{C}_{\mathrm{i}} \quad$ - selling price of specific timber grades determined by a locally competent forest inspectorate,

$\mathrm{U}_{\mathrm{i}} \quad$ - index of reduction of selling price of $1 \mathrm{~m}^{3}$ of timber, decreased by the costs of harvesting and skidding, referring to specific timber grades, applied by a locally competent forest inspectorate,

$\mathrm{V}_{\mathrm{DR}} \quad$ - volume of small-sized timber,

$\mathrm{k}_{\mathrm{DR}} \quad$ - index converting total volume of small-sized timber into volume of usable small-sized timber having commercial value,

$\mathrm{C}_{\mathrm{DR}} \quad$ - selling price of usable small-sized timber.

The first stage in the calculations is to determine the gross volume of timber (VG) based on the quantity and quality of the trees in the valuation area. Based on the performed surveys, this stage should be implemented using the volume tables of butt-end logs and standing trees (STANDARD 2004). 
The tree volume coefficients are selected for specific species of a tree, its height in meters and DBH diameter at breast height - in centimeters. The results of gross volume for individual tree species are set out in a field journal.

The next step involves the calculation of the net volume of timber with respect to use grades, using the $r_{i}$ coefficients (CZURAJ 1991).

The reduction index of the selling price of $1 \mathrm{~m}^{3}$ of timber, decreased by the costs of harvesting and skidding, is calculated according to the following formula:

$$
U=1-\frac{K_{p}+K_{z}}{C}
$$

where:

$K_{p} \quad$ - costs of harvest of a particular timber grade according to data from a forest inspectorate,

$\mathrm{K}_{\mathrm{z}} \quad$ - costs of skidding of a particular timber grade according to data from a forest inspectorate,

C - current price of $1 \mathrm{~m}^{3}$ of timber from a local market or a locally competent forest inspectorate.

This price should not include VAT.

The second possible technique, also used in this research study, is the index-based valuation approach (Fig. 2). It is usually used to calculate values of stands that have developed medium-sized grades (older than 20 years). The detailed procedure and its practical application were presented by the author in (BALAWEJDER et al. 2015); in the present paper, it will not be analyzed in the theoretical part of the methodology, but only applied in the practical part of the research.

\section{Empirical results}

The subject of the valuation is Subarea No. 170d. It is located in Tenczynek Landscape Park (district of Krakow, municipality of Krzeszowice). Subarea 170d is located in the Tenczynek Forest Division, which is part of the Krzeszowice Forest Inspectorate (Fig. 3).
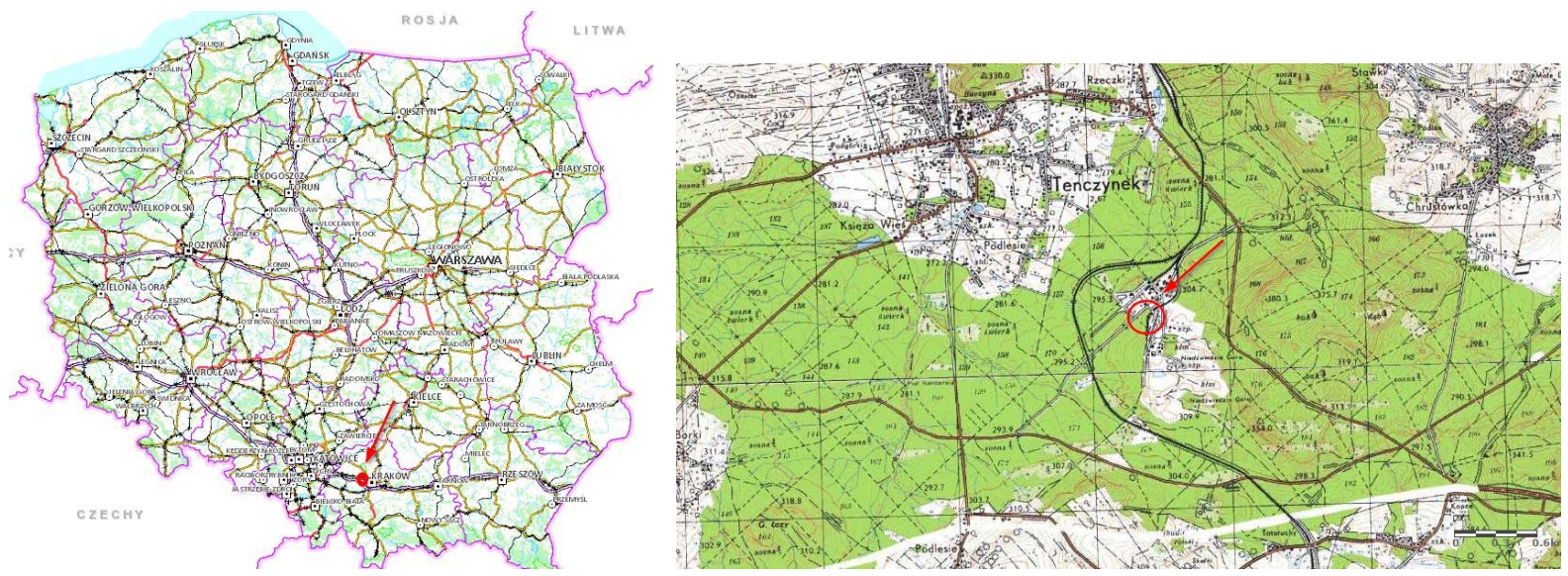

Fig. 3. Location of the subarea. Source: http://mapy.geoportal.gov.pl/.

Subarea 170d is part of Record Parcel No. 1846/1. In the forest management plan, the surface area of the valued subarea is 0.54 ha.

\subsection{Land valuation}

The discussed subarea borders a fire road from the north-west side and a high-voltage power line from the north-east side, while its boundary from the south side runs along a watercourse. At the same time, the subarea is adjacent to another one from the south-east to the south-west, where different species of trees predominate. Thanks to such a location, its boundaries are relatively clear and easy to identify in field (Fig. 4).

\subsubsection{Land valuation based on the data from a forest management plan}

Formula (2) was used to calculate the value of land using the land valuation index method. The surface of Subarea 170d for the calculations was adopted from the forest management plan. In addition, the following parameters were set: 
$\mathrm{N}=24 \mathrm{~m}^{3} \mathrm{dr} / \mathrm{ha}$ - forest land valuation index for the forest site type of moist mixed forest and for II tax district was determined based on (REGULATION 2001) and (REGULATION 2004) (Valuation indices in $\mathrm{m}^{3}$ of timber from 1 ha of forest land),

$\mathrm{P}=0.54$ ha - area of forest land (derived from forest management plan),

$\mathrm{c}=196.35 \mathrm{PLN}$ - price of $1 \mathrm{~m}^{3}$ of timber, as a weighted average, taking into account usable grades of timber, less the costs of its harvest and skidding in 2016, according to data from the Krzeszowice Forest Inspectorate (price of timber and costs of harvest and skidding in the Krzeszowice Inspectorate).
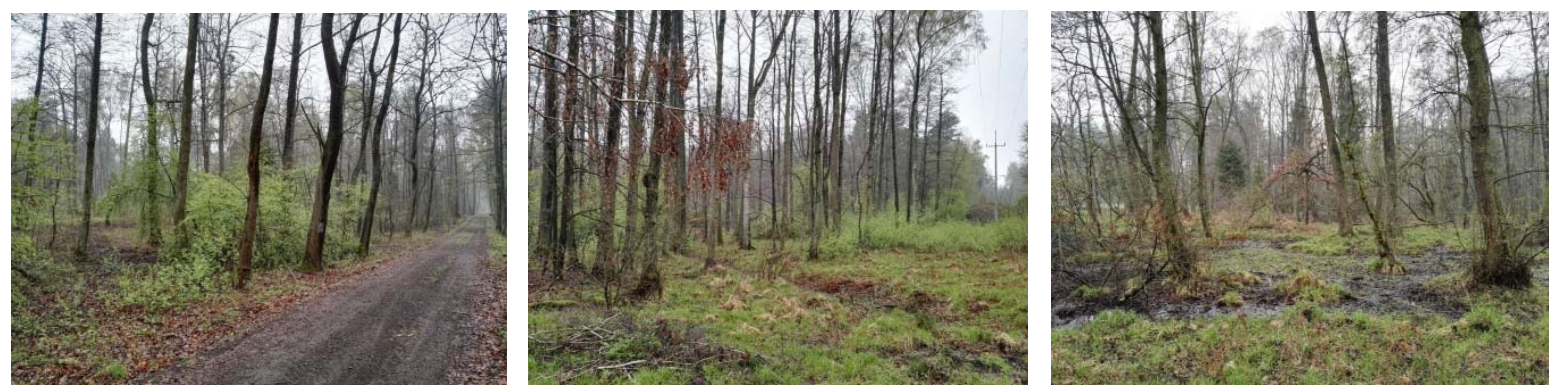

Fig. 4. Boundaries of Subarea 170d. [Source: own study]

During the field inspection, the qualities of the forest land being valued were described: $\mathrm{v}_{1}$ - degree of degradation of a forest site - slight $\mathrm{v}_{1}=0.05$

$\mathrm{v}_{2}$ - location of a property within reach of harmful effects of industry on the stands (abiotic factors) weak damage $\mathrm{v}_{2}=0.05$

$\mathrm{v}_{3}$ - location of a property in areas threatened by the mass occurrence of primary pests - does not occur $\mathrm{v}_{3}=0.05$

$\mathrm{V}_{4}$ - location of a property in areas threatened by the occurrence, or with the occurrence, of secondary pests - does not occur $\mathrm{v}_{4}=0.05$

$\mathrm{V}_{5}$ - location of a property relative to a main road or a site plot - very good $\mathrm{v}_{5}=0.1$

$\mathrm{v}_{6}$ - possibility of skidding (conditions) - very good $\mathrm{v}_{6}=0.2$

$\mathrm{v}_{7}$ - quality of access road - very good $\mathrm{v}_{7}=0.1$

$\mathrm{v}_{8}$ - adjacent land use areas - very favorable $\mathrm{v}_{8}=0.05$

$\mathrm{v}_{9}$ - adjacent land use areas - very favorable $\mathrm{v}_{9}=0.1$

The above-mentioned correction coefficients (vi) were determined during the field inspection alone, and their numerical values were adopted based on (COMMENTARY 2004) and summarized in Table 1.

Table 1

Summary of data for calculating market value of land using the land valuation index method

\begin{tabular}{|c|c|c|c|c|c|c|c|c|c|c|c|c|}
\hline \multirow{2}{*}{ Subarea } & \multirow{2}{*}{$\begin{array}{c}\mathrm{N} \\
{\left[\mathrm{m}^{3} \mathrm{dr} / \mathrm{ha}\right]}\end{array}$} & \multirow{2}{*}{$\begin{array}{c}\text { Surface } \\
\text { area } \\
\text { [ha] }\end{array}$} & \multirow{2}{*}{$\begin{array}{c}\mathrm{C} \\
{[\mathrm{PLN}]}\end{array}$} & \multicolumn{9}{|c|}{ Correction coefficients $\left[\mathrm{v}_{\mathrm{i}}\right]$} \\
\hline & & & & $\mathrm{v}_{1}$ & $\mathrm{~V}_{2}$ & $\mathrm{~V}_{3}$ & $\mathrm{v}_{4}$ & $\mathrm{~V}_{5}$ & $\mathrm{v}_{6}$ & $\mathrm{~V}_{7}$ & $\mathrm{~V}_{8}$ & $\mathrm{~V}_{9}$ \\
\hline $170 d$ & 24 & 0.54 & 196.35 & 0.05 & 0.05 & 0.05 & 0.05 & 0.1 & 0.2 & 0.1 & 0.05 & 0.1 \\
\hline
\end{tabular}

Source: Own study.

The market value of land calculated by Formula (2) is as follows:

$\mathrm{W}_{\mathrm{G}}=24 \mathrm{~m}^{3} \mathrm{dr} / \mathrm{ha} \times 0.54 \mathrm{ha} \times 196.35 \mathrm{PLN} / \mathrm{m}^{3} \mathrm{dr} \times(1+0.05+0.05+0.05+0.05+0.1+0.2+0.1++$ $0.05+0.1)=\underline{\mathbf{4}}, \mathbf{4 5 3 . 2 2}$ PLN.

\subsubsection{Land valuation based on geodetic survey results}

In order to determine the surface area of Subarea $170 \mathrm{~d}$ its boundaries were measured using the combined method, with the use of a Leica TC407 total station and Geosun GPS receiver. A four-point geodetic control was established and the surveys were performed by the GPS-RTN method (points PS1, PS2) and the tacheometric method (closed sequence of polygonal numbers, linearly and angularly tied to the side PS1, PS2). 
Adjustment of observations was carried out together as a single-row control. Mean error of point position was $0.006 \mathrm{~m}$, and $\mathrm{m} 0$ was 1.12 . C-GEO v.8.1 was used for the calculations. Lines joining 7 turn points formed the boundaries of the subarea. The course of the boundaries was adopted based on the analysis of the stand species and on the basis of natural boundaries occurring in the area, such as watercourses, roads, or high voltage lines. Economic maps provided by the Krzeszowice Forest Inspectorate were used as support materials. Based on the measurements of the turn points of the subarea boundaries, its surface area was calculated, which amounted to 0.5954 ha.

A sketch of the geodetic control, together with the subarea boundary points, has been demonstrated in Figure 5.

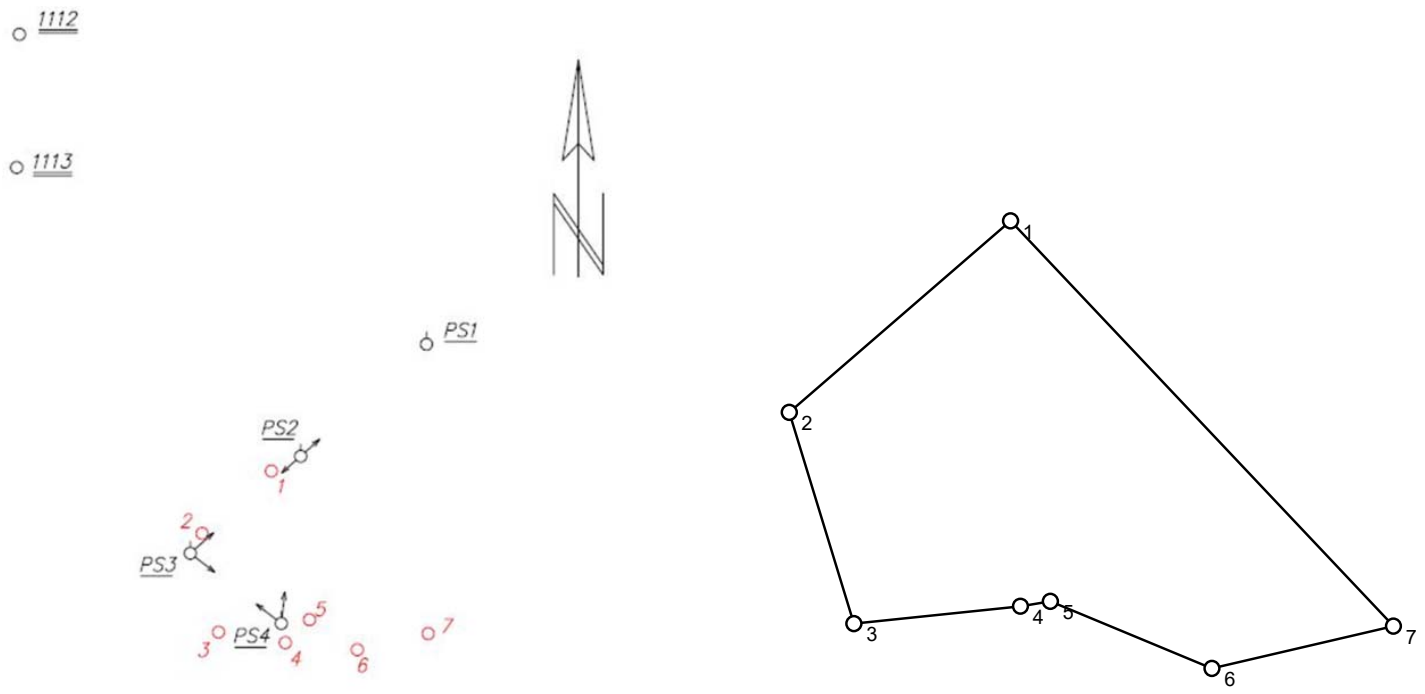

Fig. 5. Sketch of geodetic control with boundary points of Subarea 170d. Source: own study.

Figure 6 demonstrates a comparison of the course of the boundaries of the discussed subarea. The boundaries from direct surveys are marked in red, whereas the boundaries based on a numerical forest map attached to the forest management plan obtained from the Krzeszowice Forest Directorate - in blue.

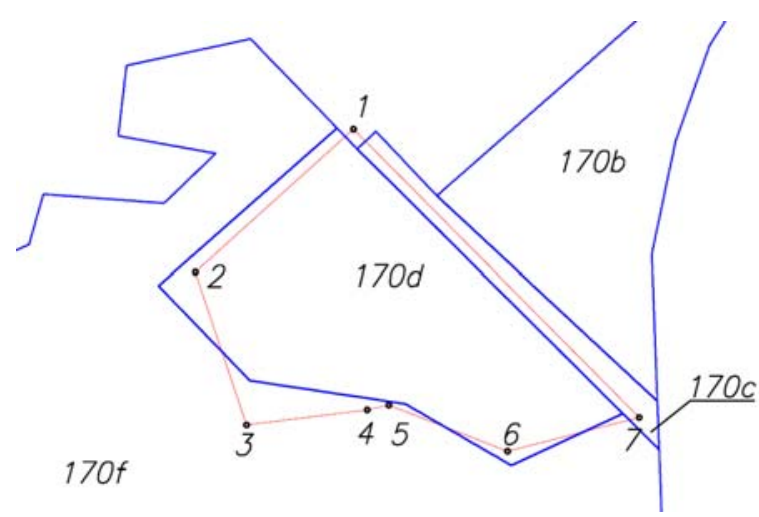

Fig. 6. Comparative sketch of the boundaries of Subarea 170d. Source: own study.

In determining the value of land based on direct surveys, the value of only one factor was changed in Formula (2) - surface area of Subarea 170d. Other parameters remained unchanged. The value of land can, therefore, be written as:

$$
\begin{gathered}
\mathrm{W}_{\mathrm{G}}=24 \mathrm{~m}^{3} \mathrm{dr} / \mathrm{ha} \times 0.5954 \mathrm{ha} \times 196.35 \mathrm{PLN} / \mathrm{m}^{3} \mathrm{dr} \times(1+0.05+0.05+0.05+0.05+0.1+0.2+0.1+0.05 \\
+0.1)=\underline{\mathbf{4}, 910.09 \mathrm{PLN}}
\end{gathered}
$$

\subsection{Forest stand valuation}

Valuation of the analyzed stand was also carried out using a mixed approach, the land valuation index method, based on two sources: data contained in the updated forest management plan and data from individual tree assessment. 


\subsubsection{Forest stand valuation - index-based valuation approach based on updated forest management plan}

In the forest management plan for the Krzeszowice Forest Inspectorate (PLAN 2012) for Subarea 170d, with a surface area of 0.54 ha, the forest site type was specified as a moist mixed forest (LMW), the Minimum Cutting Age was defined as 80, and tree cover - as 0.9. Assessment descriptions set out the following shares of specific species in the stand, as well as its characteristics:

- OL (Alder), share: 10 (whole area), age 94, valuation class II,

- BRZ (Birch), share: local occurrence, age 94. as follows:

The remaining parameters which were determined in the Krzeszowice Forest Inspectorate are

Average cost of $1 \mathrm{~m}^{3}$ timber (all species) for 2016 in Krzeszowice Forest Inspectorate - $C=$ 258.36 PLN

Average cost of harvesting $1 \mathrm{~m}^{3}$ of timber in Krzeszowice Forest Inspectorate - 29.58 PLN

Average costs of skidding $1 \mathrm{~m}^{3}$ of timber in Krzeszowice Forest Inspectorate - 31.36 PLN

The following data were taken for the calculations:

$\mathrm{W}_{\mathrm{Si}}$ - value index of 1 ha of unharvested stand expressed in $\mathrm{m}^{3}$ of timber, 94 years for alder (80 years was adopted), valuation class II, and a Minimum Cutting Age of 80 years - 69.1 - based on (REGULATION 1985),

$\mathrm{Z}_{\mathrm{i}} \quad$ - tree cover -0.9

P - area of the stand - 0.5954 ha,

C price of $1 \mathrm{~m}^{3}$ of sawmill timber (all species), according to Krzeszowice Forest Inspectorate 258.36 PLN/m³,

$\mathrm{U} \quad$ - index reducing the selling price of sawmill timber (all species) by the costs of harvesting and skidding, calculated from Formula (4), using the values $\mathrm{K}_{\mathrm{p}}$ and $\mathrm{K}_{\mathrm{z}}$ :

$\mathrm{K}_{\mathrm{p}} \quad=29.58 \mathrm{PLN} / \mathrm{m}^{3}, \mathrm{~K}_{\mathrm{z}}=31.36 \mathrm{PLN} / \mathrm{m}^{3}$

$$
U=1-\frac{29.58 P L N+31.36 P L N}{258.36 P L N}=0.764
$$

The market value of the stand, calculated according to (STANDARD 2004) (BALAWEJDER et al. 2015), using the index-based valuation approach, including data from the forest management plan, is as follows:

$$
W_{D}=W_{S i} \times Z_{i} \times P_{i} \times C \times U
$$

$$
\mathrm{W}_{\mathrm{D}}=69.1 \times 0.9 \times 0.5954 \mathrm{ha} \times 258.36 \mathrm{PLN} / \mathrm{m}^{3} \times 0.764=\underline{7,308.83} \mathbf{P L N}
$$

\subsubsection{Forest stand valuation - stock survey approach}

Field works aimed at estimating the number of trees and the quality of timber grades were performed using the stock survey approach. The individual tree assessment method was used as the most accurate one, because it takes all the trees occurring in a specific subarea into account. The field works were carried out in the spring, so given the appearance of the leaves, the shape of the tree crowns and the structure of the bark, it was easy to identify individual tree species.

The measurement methodology was based on the following stages of work:

- All trees growing in the above-mentioned subarea were measured - their DBH - diameter at breast height (diameter of a tree at $1.30 \mathrm{~m}$, counting from the highest soil level around a tree) and height. DBH was measured twice, in a crisscross pattern - at the smallest and largest diameters. The diameter of a tree at breast height is the arithmetic mean of both measurements. Tree height measurements were performed using an optical altimeter.

- Species of trees were defined and overall classification of the measured trees into qualitative and dimensional grades was carried out. The prevailing species was alder, but beech, ash, oak, as well as single specimens of birch, spruce, linden and willow were also present. The results of the measurements were included in the field journal.

- Average tree heights for DBH ranges were determined for the individual species.

- Gross volume of individual trees was specified according to the tables (CZURAJ 1991). Subsequently, the gross volume for each tree species was summarized in individual DBH ranges.

- Gross volume was converted into net volume, based on (GUIDELINE 2012). 
- Subsequently, the calculated net volume was divided into qualitative and dimensional timber grades by determining the percentage share of each of the grades.

The results of the described activities are contained in the tables, separately for each tree species. Due to the limited length of this paper, only the results for the leading species - alder - have been presented (Table 2). In the course of the studies, similar tables were prepared for the other tree species occurring in Subarea $170 d$.

Table 2

Classification of volume into qualitative and dimensional grades, according to tree species

\begin{tabular}{|c|c|c|c|c|c|c|c|c|c|c|}
\hline Species: & & & & Alder & & & & & & \\
\hline 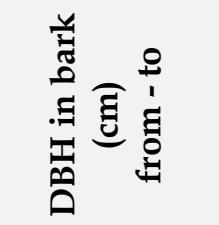 & 岁 & 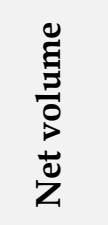 & 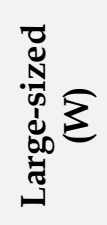 & 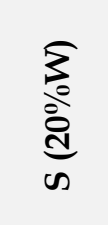 & 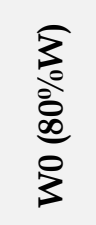 & 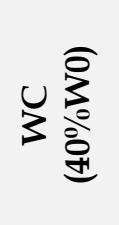 & 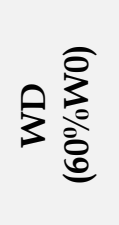 & 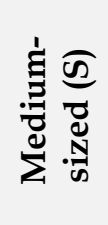 & $\begin{array}{l}\text { कृ } \\
\text { îे } \\
\text { के }\end{array}$ & 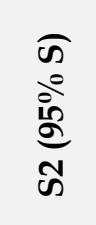 \\
\hline $9-10$ & 0.06 & 0.04 & & & & & & & & \\
\hline $11-19$ & 1.19 & 0.87 & & & & & & 12.41 & 0.62 & 11.79 \\
\hline $20-29$ & 15.75 & 11.50 & & & & & & & & \\
\hline $30-39$ & 61.12 & 44.62 & \multirow{4}{*}{96.90} & \multirow{4}{*}{19.38} & \multirow{4}{*}{77.52} & \multirow{4}{*}{31.01} & \multirow{4}{*}{46.51} & \multirow{4}{*}{19.38} & \multirow{4}{*}{0.97} & \multirow{4}{*}{18.41} \\
\hline $40-49$ & 44.93 & 33.69 & & & & & & & & \\
\hline $50-60$ & 21.00 & 15.75 & & & & & & & & \\
\hline more than 60 & 3.68 & 2.84 & & & & & & & & \\
\hline \multicolumn{4}{|c|}{ Total } & & & 31.01 & 46.51 & & 1.59 & 30.20 \\
\hline
\end{tabular}

Source: Own study.

The other indices necessary to implement Formula (3) are the same as for the index-based valuation approach. Having consulted a forestry expert in the Krzeszowice Forest Inspectorate, the final calculations of the stand value did not include the value of small-sized timber which is Included in Formula (3). This was due to the fact that small-sized timber in Krzeszowice was not a commercial material. The market value of the stand is as follows:

$\mathrm{W}_{\mathrm{D}}=109.31 \times 258.36 \mathrm{PLN} \times 0.764+9.16 \times 258.36 \mathrm{PLN} \times 0.764+6.74 \times 258.36 \mathrm{PLN} \times 0.764+12.93 \times$ 258.36 PLN x 0.764 + 5.65 x 258.36 PLN x 0.764 + 0.02 x 258.36 PLN x 0.764 + 0.24 x 258.36 PLN x 0.764

$$
+0.18 \times 258.36 \mathrm{PLN} \times 0.764=\underline{\mathbf{2 8}, \mathbf{4 7 5 . 1 1} \mathbf{P L N}}
$$

\section{Discussion and conclusions}

The value of a forest property is the sum of the value of forest land and its components, such as stands and single trees. In the case of the analyzed forest property - Subarea $170 \mathrm{~d}$ - these values, calculated by Formula (1), are as follows (Table 3).

Table 3

Results of forest property values

\begin{tabular}{cccc}
\hline $\begin{array}{c}\text { Applied valuation technique } \\
\text { (source of data acquisition) }\end{array}$ & $\begin{array}{c}\text { Value of land } \\
\text { [PLN] }\end{array}$ & $\begin{array}{c}\text { Value of } \\
\text { forest stand } \\
\text { [PLN] }\end{array}$ & $\begin{array}{c}\text { Value of real } \\
\text { property } \\
\text { [PLN] }\end{array}$ \\
\hline $\begin{array}{c}\text { Index-based valuation } \\
\text { approach }\end{array}$ & $4,453.22$ & $7,308.83$ & $\underline{\mathbf{1 1 , 7 6 2 . 0 5}}$ \\
$\begin{array}{c}\text { (Forest management plan) } \\
\text { Stock survey approach } \\
\text { (individual tree assessment) }\end{array}$ & $4,910.09$ & $28,475.11$ & $\underline{\mathbf{3 3 , 3 8 5 . 2 0}}$ \\
\hline
\end{tabular}

Source: Own study. 
As far as the value of land is concerned, divergence of the results is relatively small (about 10\%) and is due exclusively to the difference in the values of the surface area of the analyzed subarea. The other parameters are the same in both methods, the correction factors were determined in field during the site inspection.

Particular attention should be paid to the large discrepancy in the values of the stand. This difference is mainly due to the fact that assessment descriptions from the forest management plan contain solely a description of the species prevailing in a specific subarea. In the study site, this was mostly alder (100\% share according to the forest management plan), with the local occurrence of birch. Birch trees were not taken into account in the index-based valuation approach because their share according to the assessment data was $0 \%$. However, during the site inspection and during the implementation of the stock survey procedure, it turned out that there were actually other numerous species of trees, such as birch, beech, oak, ash, linden, willow and single specimens of spruce (Table 4).

Table 4

Data used to calculate the stand with index-based valuation approach and stock survey approach

\begin{tabular}{|c|c|c|c|c|c|c|c|}
\hline & & & \multicolumn{5}{|c|}{$\begin{array}{l}\text { Applied valuation technique (source of valuation data } \\
\text { acquisition) }\end{array}$} \\
\hline & & & \multicolumn{2}{|c|}{$\begin{array}{c}\text { Index-based valuation } \\
\text { approach } \\
\text { (Forest management } \\
\text { plan) }\end{array}$} & \multicolumn{3}{|c|}{$\begin{array}{c}\text { Stock survey approach } \\
\text { (individual tree assessment) }\end{array}$} \\
\hline \multirow{13}{*}{ 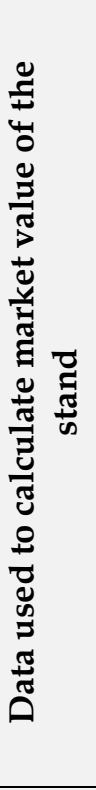 } & \multicolumn{2}{|c|}{ Subarea } & \multicolumn{5}{|c|}{$170 d$} \\
\hline & \multicolumn{2}{|c|}{ Surface area } & \multicolumn{2}{|c|}{0.5954 ha } & \multicolumn{3}{|c|}{0.5954 ha } \\
\hline & \multicolumn{2}{|c|}{$\begin{array}{l}\text { Value index for } 1 \text { ha of } \\
\text { forest stand }\left[W_{s}\right]\end{array}$} & \multicolumn{2}{|c|}{69.1} & \multicolumn{3}{|c|}{ - } \\
\hline & \multicolumn{2}{|c|}{ Tree cover $[\mathrm{Z}]$} & \multicolumn{2}{|c|}{0.9} & \multicolumn{3}{|c|}{-} \\
\hline & & & $\begin{array}{c}\text { Price in } \\
\text { PLN } \\
{\left[\mathrm{C}_{\mathrm{i}}\right]}\end{array}$ & $\begin{array}{c}\text { Costs of } \\
\text { harvesting } \\
\text { and } \\
\text { skidding } \\
{\left[U_{i}\right]} \\
\end{array}$ & $\begin{array}{c}\text { Volume } \\
\text { in } \mathrm{m}^{3} \\
{[\mathrm{Vi}]}\end{array}$ & $\begin{array}{c}\text { Price } \\
\text { in PLN } \\
{\left[\mathrm{C}_{\mathrm{i}}\right]}\end{array}$ & $\begin{array}{c}\text { Costs of } \\
\text { harvesting } \\
\text { and } \\
\text { skidding } \\
{\left[\mathrm{U}_{\mathrm{i}}\right]} \\
\end{array}$ \\
\hline & \multirow{8}{*}{ 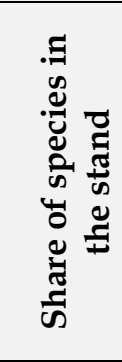 } & Alder & 258.36 & 0.764 & 109.31 & 258.36 & 0.764 \\
\hline & & Birch & - & - & 6.74 & 258.36 & 0.764 \\
\hline & & Beech & - & - & 9.16 & 258.36 & 0.764 \\
\hline & & Oak & - & - & 12.93 & 258.36 & 0.764 \\
\hline & & Ash & - & - & 5.65 & 258.36 & 0.764 \\
\hline & & Linden & - & - & 0.02 & 258.36 & 0.764 \\
\hline & & Willow & - & - & 0.24 & 258.36 & 0.764 \\
\hline & & Spruce & - & - & 0.18 & 258.36 & 0.764 \\
\hline \multicolumn{3}{|c|}{ Value of the stand } & \multicolumn{2}{|c|}{$7,308.83$} & \multicolumn{3}{|c|}{$28,475.11$} \\
\hline
\end{tabular}

Source: Own study.

The value of the stand was also affected by the surface area of the analyzed subarea. The one from the surveys was greater than that from the assessment descriptions by 0.06 ha, which represents about $10 \%$ of the total surface area of the subarea. This is consistent with the assumptions contained in (BALAWEJDER et al. 2015) regarding the uncertainty of determining the value of a stand depending on the uncertainty of determining the surface area of a subarea.

Having analyzed the formulas used to calculate the value of the stand, it is evident that its final value obtained by two different valuation techniques is calculated based on different data. When calculating the market value of the stand using the index-based valuation approach, factors which were taken into account included: surface area, valuation index of 1 hectare of the stand, tree cover, price of timber, as well as the costs of harvesting and skidding. On the other hand, in the calculations using the stock survey approach, the main factor to be taken into consideration was the weight of timber obtained by the method of individual tree assessment - the most reliable data reflecting the actual status in field. The remaining factors included surface area, the price of timber, as well as the 
costs of harvesting and skidding. It may be concluded therefrom that the main determinants of the final market value of a stand include the share of species and the actual weight of timber. In the indexbased valuation approach, failure to include the weight of timber in the calculations in actual shares of species resulted in what was an approximately three times lower market value of the stand than in the stock survey approach.

Current legal regulations on property valuation, such as the Real Estate Management Act (ACT 1997) and the Regulation on real property valuation and preparation of a property valuation survey (REGULATION 2004), directly regulate the issues of forest land valuation. As for the valuation of a forest stand, however, the law does not specify procedures to be used to estimate the value of forest stands. In practice, the instructional standard is used - Professional Standard V.6 "Valuation of Forest Properties as well as Wooded and Shrubbed properties". However, it should be emphasized that this is only an Interpretative Note and not a legal provision, it may only be helpful in the valuation process.

As it appears from the analysis of the results of the study carried out in a subarea representative of southern Poland, valuation using solely the data contained in forest management plans, even after their update in the State Forest Information System, does not allow for the reliable valuation of a stand. Forest management plans should be treated as supporting materials only, and used by real estate valuers in establishing forest site types and, partially, with economic maps, in determining the boundaries of subareas.

In conclusion, it may be stated that, currently, the process of the valuation of forest stands as components of forest real properties does not enjoy sufficient legal protection. The results of the conducted research demonstrate that values of the forest stand determined by the index-based valuation approach and the stock survey approach differ significantly, at least for subareas with a variety of tree species. The thesis of this study that the use of the index-based valuation approach is not to be recommended has thus been proven.

\section{References}

AbdollahnejAd, A., PAnAgiotidis, D., Joybari, S.S., Surovy, P., 2017, Prediction of Dominant Forest Tree Species Using QuickBird and Environmental Data. FORESTS, Volume: 8, Issue: 2, Article Number: 42, DOI: $10.3390 /$ f8020042.

ACT, 1991, Act of 28 September 1991 on forests (Journal of Laws of 1991, No. 101, item 444).

ACT, 1997, Act of 21 August 1997 on Real Estate Management (Journal of Laws of 1997, No. 115, item 741), as amended).

BALAWEJDER M., BUŚKO M., CELLMER R., JUCHNIEWICZ-PIOTROWSKA K., LEŃ P., MIKA M., SZCZEPANKOWSKA K., WÓJCIAK E., WÓJCIK-LEŃ J., ŹRÓBEK S., 2015, Aktualne problemy gospodarki nieruchomościami w Polsce na tle przemian organizacyjno-prawnych. (The Current Problems of Real Estate Management in Poland Against the Background of Organizational and Legal Changes). Rzeszów, Wyższa Szkoła Inżynieryjno-Ekonomiczna, 2015. 144 s. ISBN: 978-83-60507-20-9. http:/ / wsie.edu.pl/wp-content/uploads/2014/06/aktualne-problemy-srodek.pdf

COMMENTARY 2004: Commentary to the Standard V.6 "Valuation of Forest Properties as well as Wooded and Shrubbed Properties", PFSRM, 8th edition, extended, 2004.

Crosby M., Matney T., Schultz E., Evans D., Grebner D., LONDO H., RodGers J., Collins C., 2017, Consequences of Landsat Image Strata Classification Errors on Bias and Variance of Inventory Estimates: A Forest Inventory Case Study. IEEE JOURNAL OF SELECTED TOPICS IN APPLIED EARTH OBSERVATIONS AND REMOTE SENSING, Volume: 10 Issue: 1 Pages: 243-251 DOI: 10.1109/JSTARS.2016.2597762

CSO, 2016, Central Statistical Office, Department of Agriculture and Forestry 2015, Warsaw 2015, http:/ / stat.gov.pl/obszary-tematyczne/rolnictwo-lesnictwo/ - accessed on 15.12.2016.

CZUrAj M., 1991, Tablice miąższości kłód odziomkowych o drzew stojących (Volume Tables of Butt-end Logs and Standing Trees, Polskie wydawnictwo Rolnicze i Leśne, Warszawa 1991.

DUDZIŃSKA M., KOCUR-BERA K., 2014, Information on the Environment and its Protection in Real Property Management, Real Estate Management and Valuation, Vol. 22, No. 3, pp. 93-103.

GUIDELINE, 2012, Forest Management Guideline, Ministry of Environmental Protection, Natural Resources and Forestry and Directorate General of State Forests, Warsaw 2012. 
KuCHARSKA-STASIAK E., ŹRÓBeK S., 2015, An Attempt to Exemplify the Economic Principles in Real Property Valuation, Real Estate Management and Valuation, Vol. 23, No. 3, pp. 5-13.

Mikita T., JANATA P., Surovy P., 2016, Forest Stand Inventory Based on Combined Aerial and Terrestrial Close-Range Photogrammetry. Forests, Volume: 7 Issue: 8 Article Number: 165 Published: AUG 2016, DOI: $10.3390 /$ f7080165.

MOHAMmADI, Z., LIMAEI, S.M., SHAHRAJI, T.R., 2017, Linear Programming Approach for Optimal Forest Plantation. JOURNAL OF FORESTRY RESEARCH, Volume: 28, Issue: 2, Pages: 299-307, DOI: 10.1007/s11676-016-0318-y

ORDER, 1985, Order No. 14 of the Minister of Forestry and Wood Industry of 23 August 1985 on the Principles of Determining the Value of Stands (Official Journal of the Ministry of Forestry and Wood Industry No. 2, item 7 - partially repealed).

PARTYKA T., TRAMPLER T., 1991, Tables of Forest Stand Valuation Indices, Forest Research Institute, 1991.

PLAN, 2012, Forest Management Plan, Krzeszowice Forest Inspectorate, 2012.

REGULATION, 2001, Regulation of the Minister of Finance of 10 December 2001 on the Classification of Municipalities and Cities into One of the Four Tax Districts (Journal of Laws of 2001, No. 143, item 1614).

REGULATION, 2004, Regulation of the Council of Ministers of 21 September 2004 on Real Property Valuation and Preparation of a Property Valuation Survey (Journal of Laws of 2004, No. 207, as amended).

SCHWEIZER, S.A., FISCHER, H., HARING, V., STAHR, K., 2017, Soil Structure Breakdown Following Land Use Change from Forest to Maize in Northwest Vietnam. SOIL \& TILLAGE RESEARCH, Volume: 166, Pages: 10-17, DOI: 10.1016/j.still.2016.09.010.

STANDARD, 2004, Standard V.6 "Valuation of Forest Properties as well as Wooded and Shrubbed Properties", PFSRM, 8th edition, extended, 2004.

WILKOWSKI, W., 2011, Zasady określania wartości drzewostanów w procedurach określania wartości nieruchomości leśnych (Rules for Determining the Value of Tree Stands in Valuation Procedures of Forest Real Estate) Rzeczoznawca Majątkowy 1, 2011, pp. 30-38.

WILKOWSKI, W. 2013, Wpływ na wartość nieruchomości leśnych petnionych przez nie funkcji ochronnych, rekreacyjnych oraz krajobrazowych (Influence of Protection, Recreation and Landscape Functions Served by Forest Real Estate on their Value) Rzeczoznawca Majątkowy 1(77), 2013, pp. 22-29.

ZAJAcC S., 2013, Wartościowanie lasu w teorii i praktyce (Forest Valuation in Theory and Practice), Panel Ekspertów (Panel of Experts) „Wartość - Lasy jako czynnik rozwoju cywilizacji, współczesna i przyszła wartość lasów” (Value - Forests as a factor of civilizational development, current and future value of forests), Sękocin, 2013.

VAYSSE, K., LAGACHERIE, P., 2017, Using Quantile Regression Forest to Estimate Uncertainty of Digital Soil Mapping Products. GEODERMA, Volume: 291 Pages: 55-64. DOI: 10.1016/j.geoderma.2016.12.017 